\title{
Community Participation in Ecotourism Management with Special Reference to Athirappilly and Vazhachal
}

\author{
K. Sooraj Menon \\ Department of Commerce, Sree Vyasa N.S.S. College, Thrissur, Kerala, India \\ E-Mail: informmenon@gmail.com
}

\begin{abstract}
The objectives of Ecotourism can be achieved if there is a well planned mechanism to manage destinations. Among the stakeholders of ecotourism projects, the host community of is the most important one. It is through them the ideology of ecotourism can be popularised. This paper investigates the factors that influence host community participation in ecotourism management of Athirappilly and Vazhachal - two popular ecotourism destinations of Kerala. The involvement of the host community in management of ecotourism destinations will help them to empower themselves while ensuring management of natural resources in an efficient manner. This destination centric study, unlike the other macro level studies, attempts to understand the factors influencing community participation in ecotourism management at Athirappilly and Vazhachal. It was found that Environmental Knowledge for Sustainable Development and Perceived Economic Impact of Community Based Ecotourism Management has more influence on Participation in Community Based Ecotourism Management.

Keywords: Community Participation, Ecotourism,
\end{abstract} Athirappilly-Vazhachal, Host Community

\section{INTRODUCTION}

Athirappilly-Vazhachal ecotourism sites are part of the 413.94 square kilometres Vazhachal Forest Division. Apart from its ecotourism value this stretch of forest is unique on account of its ecological, floral, geomorphologic and cultural significance. The division harbours a wide range of plant species which include 823 species of flowering plants of which 138 are endemic to the Southern Western Ghats and peninsular India. Chalakudy- Anamalai road owes its scenic beauty to this wonderful floral diversity. Vazhachal forest division is an excellent representation of the faunal diversity of Western Ghats. This is also the home to two tribal communities namely Kadar and Malayar. There are nine settlements of these communities in this division, who depend entirely on this forest for their existence.

Community participation in ecotourism management and the factors affecting community participation are not studied at micro level in Kerala. Four variables including environmental knowledge for sustainable development, motivation to be involved with Community Based Ecotourism Management, perceived economic impact of Community Based Ecotourism Management and perceived social impact of Community Based Ecotourism Management was identified from literature and its influence on participation in Community Based Ecotourism
Management is studied in the context of community based ecotourism management in Athirappilly - Vazhachal ecotourism destination.

\section{STATEMENT OF THE PROBLEM}

Ecotourism development of a particular destination is a combined effort of large number of stakeholders. It includes the attitude and cooperation of tourists visiting the destination, tour operators in the destination, host community of the destination and the officials appointed by the government for regulating and developing tourism in a destination.

The lack of involvement of local communities in the establishment and management of ecotourism have always resulted in unfavourable behaviour towards sustainable and eco friendly use of natural resources. Social capital plays a pivotal role to improve cooperation and coordination of the local community for the development of community based ecotourism. The participation and involvement of local community in ecotourism will help them to empower and uplift themselves while ensuring the sustainability and manageability of natural resources in an efficient manner.

There arise questions as to what factors influence the community participation including the knowledge about environment and sustainability, motivation to be part of ecotourism management, perceived economic benefits from ecotourism and perceived social impact of ecotourism. These questions form the basis for the study. This study will attempt to understand the factors influencing community participation in ecotourism management at a single ecotourism destination. Unlike the macro level studies, this study will be destination centric and will study the factors affecting community participation at the lowest levels of ecotourism management. Studying these factors is most significant as host community is the backbone of every ecotourism destination and all dimensions of destination management and development are dependent on them.

\section{OBJECTIVES OF THE STUDY}

The objective of this study is to understand the factors affecting community participation in ecotourism. The following is the specific objective of the study: To analyze the level of influence of Environmental Knowledge for 
Sustainable Development, Motivation to be involved with Community Based Ecotourism Management, Perceived Economic Impact of Community Based Ecotourism Management and Perceived Social Impact of Community Based Ecotourism Management on Participation in Community Based Ecotourism Management at Athirappilly and Vazhachal ecotourism destination.

\section{THE CONCEPTUAL FRAMEWORK}

The conceptual framework framed for this study includes environment knowledge, motivation to be involved, perceived economic impact, perceived social impact, and participation. The indicators which forms the basis of the concepts mentioned above are defined conceptually and operationally in the coming sections. This conceptual framework provides an elementary information or skeleton about the relationships that are analysed in the study. The conceptual framework indicates the relationship between each independent variable and dependent variable. It also stipulates the combined effect of independent variables on dependent variable. The conceptual model formulated for the study is shown in the figure 1.

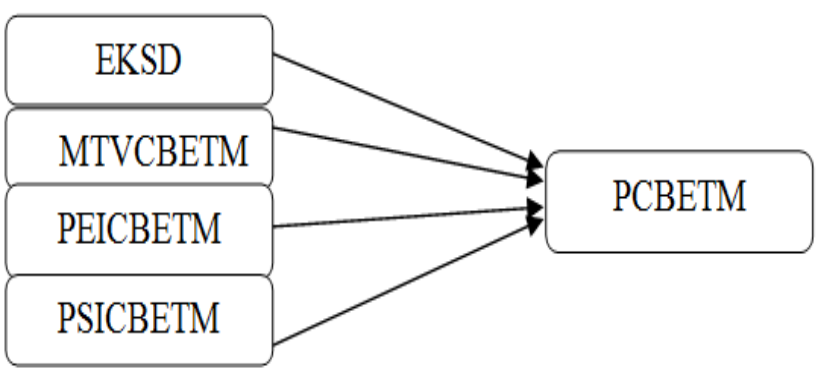

Fig. 1 Conceptual Model

EKSD - Environmental Knowledge for Sustainable Development

MTVCBETM - Motivation to be involved with Community Based Ecotourism Management

PEICBETM - Perceived Economic Impact of Community Based Ecotourism Management

PSICBETM - Perceived Social Impact of Community Based Ecotourism Management

PCBETM - Participation in Community Based Ecotourism Management

\section{CONCEPTUAL AND OPERATIONAL DEFINITIONS OF VARIABLES}

\section{A. Environmental Knowledge for Sustainable Development}

Wanga, Hayombe, Odunga and Odede (2013) found an association between residents' environmental knowledge and their attitudes towards ecotourism. Environmental knowledge is instrumental in development of ecotourism projects (Zhan \& Lei, 2012; Barr \& Gilg, 2007). Individuals who have excelled in learning the natural issues are more inclined to act in an ecological manner, ceteris paribus
(Oguz, 2011). Absence of appropriate information about the environment and misunderstanding with regards to its functioning may induce host community to act in a wrong manner (Adombent, 2013; Lozano, 2013; Vicente-Molina, 2013)

In this study, Environmental Knowledge for Sustainable Development includes the awareness about environmental sustainability, protection and conservation of natural resources, human intervention and its outcomes like ecological imbalance and climate change, knowledge about the uses of local resources, protection of local resources, awareness on sustainable development, recycling and reuse, agro forestry, and organic farming. All these factors were measured based on four indicators on a five point likert scale.

B. Motivation to be Involved with Community Based Ecotourism Management

Motivation is required for the effective participation at the community level. CBETM can motivate local communities in various ways such as bringing economic benefits, guaranteeing resources for future generations, participation in decision-making process and developing the cultural identity. The core policy of protected areas is the preservation of natural resources, so it is reasonably imperative to evaluate their social impacts on the local community to obtain the effective outcomes of conservation practices (De Lange, 2016).

In this study, Motivation to be involved with Community Based Ecotourism Management includes the belief that CBETM enhances local, host community representation in destination development plans, inevitability of CBETM for sustainable development of destination, prominent role of CBETM in securing well-being of host community and the multi dimensional support CBETM provides for inhabitants of tourism destination. All these factors were measured on four indicators on a five point likert scale.

\section{Perceived Economic Impact of Community Based Ecotourism Management}

The CBETM seeks to create equilibrium between conservation and local community livelihoods, conserving biodiversity simultaneously dropping rural poverty and accomplishing both goals on a realistic basis. CBETM is operated by locals who are responsible for administrative decisions, and profits are exclusively theirs (Khanal \& Babar, 2007).Community-based ecotourism encompasses three major laws of sustainable development i.e. economic efficiency, social value and environmental sustainability (Mbaiwa, 2004).

Economic efficiency ensures people have access and enjoy high standards of living and that benefits are shared equally among all people involved in the activity. Social equity means all the participating user groups of CBETM must 
have equal and just opportunities and access to resources as well as a fair share of revenues, right to participate in the decision-making process and administration related to tourism activity.

All members of a community involved in Community Based Ecotourism Management must benefit from the project. Ecological sustainability confirms natural resource preservation and respects the host community. CBETM ensures the community's' empowerment and ownership, conservation of natural and cultural resources, socio economic development and quality visitor experience (Hiwasaki, 2006). If used with appropriate planning and administration, CBETM can be used as a device to promote conservation and can develop rural, remote and poor communities in a suitable manner simultaneously. Sustainable development of natural resources can contribute to economic growth, improve standards of living, create job opportunities and increase the welfare of communities living near these resources (Howarth, 2012).

In this study, Perceived Economic Impact of Community Based Ecotourism Management includes the ability of CBETM to catalyse sustainable economic development, economic growth of host community and attraction of government investment to tourism destination via CBETM, widening of tourist base of destination through CBETM, financial security of host community and overall standard of living guaranteed by CBETM and economic allowances and adequate reservation for host community using CBETM. All these factors were measured on five indicators on a five point likert scale.

\section{Perceived Social Impact of Community Based Ecotourism Management}

Ecotourism creates long-term benefits that are equitably distributed between receiving communities. These benefits may be used to improve community infrastructure continually. CBETM meets communal appeal for respectable tourism leading to economic, social and ethical added value. It appears to be the most thriving form of sustainable tourism (Goodwin \& Santilli, 2009). Other focal points for CBETM are human welfare as well as social, economic and cultural viability of the host communities in the long-run. Successful implementation of communitybased ecotourism pointed towards the fact that major hurdles are a reduction of impacts, equal distribution of benefits of development and incorporated countrywide policies for rural area development (Foucat, 2002; Brandon, 1996).

CBETM has a reciprocally emphasising connection between conservation, livelihoods and cultural integrity (Hoole, 2010; Stone \& Rogerson, 2011; Tran \& Walter, 2014). Eshun \& Tonto (2014) claims that ecotourism may help in the survival of culture and help local communities to distinguish and respect their unique culture and history. Gaining success and sustain community-based tourism requires multi-institutional support. In view of the fact that community based ecosystem is a people-centric method functioning towards rational benefit share and elevating poverty, it is sure to inspire the government and the community to preserve their natural and cultural resources (Armstrong, 2012).

CBETM is a well thought out means for sustainable development. Sustainable tourism directs to the management of all resources in a way that economic, social and aesthetic needs can be fulfilled while upholding cultural integrity, essential ecological developments, natural diversity and life support scheme (Muhanna, 2006). Sole reasons for the development of community are to provide them with the essential wherewithal to improve their living conditions, to conserve their natural and cultural heritage and to offer monetary prospects (Bhatta, 2008)

In this study, Perceived Social Impact of Community Based Ecotourism Management includes the factors like improvement of cooperation and unity among members of host community, reduction of crime rate within the host community, preservation and protection of traditions and customs, cultural exchange between tourists and residents of tourism destination, respect for cultural diversity and positive social changes through CBETM among host community. All these factors were measured on five indicators on a five point likert scale.

\section{E. Participation in Community Based Ecotourism Management}

Participation of the local community helps to ensure sustainability that reduces the adverse effects of anthropogenic exercises on the environment. Local people can only achieve optimum benefits of the proposed sustainable development if they become a fundamental part of the process. For certain achievement of sustainable development, it is important that ecotourism must be a community-based initiative where the community owns and manages the business enterprises. Greater participation means more extensive economic profits are available to the communities. As that local community relies on the economic benefits, it should act as motivation for local participation in the preservation of natural and cultural resources (Coria \& Calfucura, 2012).

In this study, Participation in Community Based Ecotourism Management includes the support provided for CBETM, actual engagement in CBETM, inspiring fellow citizens to participate/ engage in CBETM, development of positive attitude on ecotourism management among family members of host community, engagement in forest protection and improvement of Non Timber Forest Produce, obligation to ensure that host community's dependence on forest for livelihood does not cause any harm or depletion to forest and its resources. All these factors were measured on six indicators on a five point likert scale. 


\section{F. Hypotheses}

Based on the objectives and the conceptual model formulated for the study the following hypotheses are formulated.

1. There exists a positive relationship between environmental knowledge for sustainable development and participation in community based ecotourism management.

2. There exists a positive relationship between motivation to be involved with community based ecotourism management and participation in community based ecotourism management.

3. There exists a positive relationship between perceived economic impact of community based ecotourism management and participation in community based ecotourism management.

4. There exists a positive relationship between perceived social impact of community based ecotourism management and participation in community based ecotourism management.

\section{METHODOLOGY OF THE STUDY}

The present study is both descriptive and explanatory in nature and both primary and secondary data were collected and used for the study. The population of the study covers all the members of Athirappilly Vana Samrakshana Samithi and Vazhachal Vana Samrakshana Samithi.

From the eleven Vana Samrakshana Samithies of Vazhachal Forest Division, Athirappilly Vana Samrakshana Samithi and Vazhachal Vana Samrakshana Samithi were selected for the study as those two are engaged in ecotourism management of Athirappilly and Vazhachal ecotourism destination. For the selection of respondents convenience sampling method was adopted. The respondents of this study include both active and dormant members of Athirappilly Vana Samrakshana Samithi and Vazhachal Vana Samrakshana Samithi. The sample size of the study is limited to 220 members of Athirappilly Vana Samrakshana Samithi and Vazhachal Vana Samrakshana Samithi.

The secondary data were collected from books, published journals, annual reports of Athirappilly and Vazhachal Vana Samrakshana Samithies, daily collection statements of Athirappilly tourist ticket counter, Final plan document of $13^{\text {th }}$ five year plan of Athirappilly Grama panchayath, annual reports of Ministry of Tourism (Government of India), annual reports of Department of Tourism (Government of Kerala), annual reports of United Nations World Tourism Organisation, Kerala forest statistics of Kerala Forest and Wildlife Department, government publications, published dissertations and thesis's. The primary data required for the study were collected from 220 members of Athirappilly Vana Samrakshana Samithi and Vazhachal Vana Samrakshana Samithi.
A structured questionnaire was developed for the collection of primary data. The first section of the questionnaire consists of the socio economic profile of the respondents. The second section of the questionnaire includes statements developed on a five point scale to measure the variables such as environmental knowledge for sustainable development, motivation to be involved with community based ecotourism management, perceived economic impact of community based ecotourism management, perceived social impact of community based ecotourism management, and participation in community based ecotourism management. The reliability of the scale of measurement used in study was assessed using Cronbach's Alpha coefficient, which was above the minimum acceptable level 0.7 , which confirmed the reliability of the scale of measurement used in the study.

The community participation in ecotourism at Athirappilly and Vazhachal and the factors affecting participation were analysed from the viewpoint of knowledge about sustainability, economic impact of participation, social impact of participation and motivation of host community to engage in ecotourism management. There may be umpteen numbers of factors which may have affected the participation of host community in ecotourism management. Data collection was done from a close knit group of members who are engaged at lower levels of ecotourism management activity in Athirappilly-Vazhachal tourism area so there are chances for their personal bias and influence of peer group while responding to the questions; but maximum care and prudence have been taken while analysing and interpreting the data so as to reach meaningful, lucid and logical conclusions.

\section{SUMMARY OF FINDINGS}

In this section, it is attempted to recapitulate the major findings which emerged from the study.

\section{A. Testing of Conceptual Model Formulated for the Study}

In order to understand the influence of independent variables on dependant variable, there should be a linear relationship between the independent variables on dependant variable. Correlation analysis was done for checking relationship between variables used in the study.

The correlation Analysis revealed that EKSD and PCBETM are significantly correlated to each other $(\mathrm{r}=0.417)$. The probability value associated with the correlation is less than 0.01. MTVCBETM and PCBETM are significantly correlated to each other $(\mathrm{r}=0.203)$. The probability value associated with the correlation is less than 0.01.PEICBETM and PCBETM are significantly correlated to each other $(r=0.243)$. The probability value associated with the correlation is less than 0.01.PSICBETM and PCBETM are significantly correlated to each other $(\mathrm{r}=0.222)$. The probability value associated with the correlation is less than 0.01 . 


\section{B. Testing the level of Influence of Independent Variables on Dependent Variable}

In order to analyse the influence of each independent variables on dependent variable simple regression analysis is done and to analyse the combined influence of independent variables on dependent variable multiple regression analysis has been done with IBM SPSS 23.0. From the simple regression analysis it is inferred that the $\beta$ value 0.417 indicates that a change in one standard deviation in EKSD will result in a change of 0.417 standard deviation in PCBETM. The $\mathrm{R}^{2}$ value of 0.170 , pointed out that this model has accounted for 17.00 per cent of variance in the PCBETM.

Table I Statistical Result Of Multiple Regression Analysis Did Using Eksd, Mtvcbetm, Peicbetm And Psicbetm On Pcbetm.

\begin{tabular}{|c|c|c|c|c|c|}
\hline \multirow{2}{*}{ Independent Variables } & \multirow{2}{*}{ Beta Value } & \multirow{2}{*}{ Sig. } & \multirow{2}{*}{$\mathbf{R}^{2}$} & \multicolumn{2}{|c|}{ Collinearity Statistics } \\
\hline & & & & Tolerance & VIF \\
\hline (Constant) & & 0.012 & \multirow{5}{*}{.216} & 2.525 & 0.396 \\
\hline EKSD & 0.366 & 0.000 & & 5.846 & 0.171 \\
\hline MTVCBETM & 0.080 & 0.218 & & 1.237 & 0.808 \\
\hline PEICBETM & 0.147 & 0.035 & & 2.125 & 0.471 \\
\hline PSICBETM & 0.050 & 0.494 & & 0.686 & 1.458 \\
\hline
\end{tabular}

From the simple regression analysis it is inferred that $\beta$ value 0.203 indicates that a change in one standard deviation in MTVCBETM will result in a change of 0.203 standard deviation in PCBETM. The $\mathrm{R}^{2}$ value of 0.037 , pointed out that this model has accounted for 3.70 per cent of variance in the PCBETM. It is inferred that $\beta$ value 0.243 indicates that a change in one standard deviation in PEICBETM will result in a change of 0.243 standard deviation in PCBETM. The $\mathrm{R}^{2}$ value of 0.055 , pointed out that this model has accounted for 5.50 per cent of variance in the PCBETM. It is inferred that $\beta$ value 0.222indicates that a change in one standard deviation in PSICBETM will result in a change of 0.222 standard deviation in PCBETM. The $\mathrm{R}^{2}$ value of 0.045 , it is visible that this model has accounted for 4.50 per cent of variance in the PCBETM.

From the multiple regression analysis, it is inferred that the Beta Value of influence of EKSD, MTVCBETM, PEICBETM, and PSICBETM are 0.366, 0.080, 0.147 and 0.050 respectively. The Beta values of independent variables EKSD, MTVCBETM, PEICBETM, and PSICBETM indicated that a change of one standard deviation will result in a change of $0.366,0.080,0.147$ and 0.050 respectively in standard deviation on PCBETM. The $\mathrm{R}^{2}$ value of 0.216 , pointed out that the model has accounted for 21.60 per cent of variance in PCBETM. VIF value is less than three which is very low so it can be inferred that there is no Multicollinearity in this model.

From the statistical results of Simple Regression Analysis and Multiple Regression Analysis it can be inferred that the level of influence of Independent Variables (EKSD, MTVCBETM, PEICBETM and PSICBETM) on the Dependent Variable (PCBETM) is low.

\section{CONCLUSION}

The present study was intended to understand the factors influencing community participation in ecotourism management of Athirappilly- Vazhachal ecotourism destination. The influence of independent variables on dependent variable is low. However, among the independent variables used for the study, EKSD and PEICBETM have more influence on PCBETM. So it would be better to take proactive measures to maintain the EKSD among community members through knowledge transfusion and provide them with more economic benefits like increase in wage rate, job security and other fringe benefits so that Participation in Community Based Ecotourism Management is improved.

Community Based Ecotourism Management provides income to community members for meeting their basic financial requirements and also enhances the awareness of sustainable living and conservation. Another important aspect of Community Based Ecotourism Management is that it upholds the concept of women empowerment and upliftment of standard of living of tribal community and brings them forward to the mainstream. Key focus shall be given to the younger generation of these disadvantaged and isolated sections of society through education and training thereby enabling them to empower themselves and bring them to the forefront in economic, social, cultural and political spheres without hampering their bond with nature and practices of sustainable living.

\section{SUGGESTIONS}

Rooted on the findings of the study, deliberations with Vana Samrakshana Samithi members, executive committee, Forest Department officials, executives of District Tourism Promotion Council, Athirappilly Panchayath members and the government officials at the data collection phase of the study, the following suggestions are made.

1. It was found that the income earned as a result of engagement in ecotourism management allows them to 
meet their basic financial requirements but many of them are of the opinion that government should deploy more funds to the destination keeping in mind the significance and economic importance of destination.

2. Proper awareness, education, training camps shall be conducted with the help of educational institutions and research centers for members of ecotourism management as well as among the tourists for the purpose of developing responsible tourism and ensuring sustainability such that ecotourism destinations are conserved for future citizens.

\section{REFERENCES}

[1] Adombent, M. (2013). Exploring universities' transformative potential for sustainability-bound learning in changing landscapes of knowledge communication. Journal of Cleaner Production, 49, 1124.

[2] Armstrong, R. (2012). An analysis of the conditions for success of community based tourism enterprises. ICRT Occasional Paper, (OP21), 1-52.

[3] Barr, S., \& Gilg, A. W. (2007). A conceptual framework for understanding and analyzing attitudes towards environmental behaviour. Geografiska Annaler: Series B, Human Geography, 89(4), 361-379.

[4] Bhatta, K. D. (2008). Urban heritage conservation: Promoting sustainable community development: A case of historic town Thimi, Nepal. HKU Theses Online (HKUTO).

[5] Brandon, K. (1996). Ecotourism and conservation: A review of key issues. The World Bank.

[6] Coria, J., \& Calfucura, E. (2012). Ecotourism and the development of indigenous communities: The good, the bad, and the ugly. Ecological Economics, 73, 47-55.

[7] Eshun, G., \& Tonto, J. N. P. (2014). Community-based ecotourism: its socio-economic impacts at Boabeng-fiema monkey Sanctuary, Ghana. Bulletin of Geography. Socio-economic Series, 26(26), 67-81.

[8] Foucat, V. A. (2002). Community-based ecotourism management moving towards sustainability, in Ventanilla, Oaxaca, Mexico. Ocean \& Coastal Management, 45(8), 511-529.
[9] Goodwin, H., \&Santilli, R. (2009). Community-based tourism: A success. ICRT Occasional paper, 11(1), 37.

[10] Hiwasaki, L. (2006). Community-based tourism: A pathway to sustainability for Japan's protected areas. Society and Natural Resources, 19(8), 675-692.

[11] Hoole, A. (2009). Place-power-prognosis: Community-based conservation, partnerships, and ecotourism enterprises in Namibia. International Journal of the Commons, 4(1).

[12] Howarth, R. B. (2012). Sustainability, well-being, and economic growth. Minding Nature, 5(2), 32-39.

[13] Khanal, B. R., \& Babar, J. T. (2007). Community based ecotourism for sustainable tourism development in the Mekong region. Policy Brief, 1, 2007

[14] Lange, E., Woodhouse, E., \& Milner-Gulland, E. J. (2016). Approaches used to evaluate the social impacts of protected areas. Conservation Letters, 9(5), 327-333.

[15] Mbaiwa, J. E. (2004). The socio-economic benefits and challenges of a community-based safari hunting tourism in the Okavango Delta, Botswana. Journal of Tourism Studies, 15(2), 37.

[16] Muhanna, E. (2006). Sustainable tourism development and environmental management for developing countries. Problems Perspect. Manag, 4(2), 14e30.

[17] Oguz, D., Cakci, I., \& Kavas, S. (2011). Environmental awareness of students in higher education. Turkish Journal of Forestry, 12(1), 3439.

[18] Stone, M. T., \&Rogerson, C. M. (2011). Community-based natural resource management and tourism: Nata bird sanctuary, Botswana. Tourism Review International, 15(1-2), 159-169.

[19] Tran, L., \& Walter, P. (2014). Ecotourism, gender and development in northern Vietnam. Annals of Tourism Research, 44, 116-130.

[20] Vicente-Molina, M. A., Fernandez-Sainz, A., \&Izagirre-Olaizola, J. (2013). Environmental knowledge and other variables affecting proenvironmental behaviour: comparison of university students from emerging and advanced countries. Journal of Cleaner Production, 61, 130-138.

[21] Wanga, J. O., Hayombe, P. O., Odunga, P. O., \& Odede, F. Z. (2013). The Nexus between environmental knowledge and ecotourism attitude among the local youths in Co-educational Secondary Schools in Bondo Sub-County, Siaya County, Kenya. International Journal of Business and Social Research, 3(7), 103-116.

[22] Zhang, H., \& Lei, S. L. (2012). A structural model of residents' intention to participate in ecotourism: The case of a wetland community. Tourism Management, 33(4), 916-925. 